University of New Hampshire

University of New Hampshire Scholars' Repository

Crimes Against Children Research Center

Research Institutes, Centers and Programs

$6-2000$

\title{
Kidnaping of Juveniles: Patterns From NIBRS.
}

\author{
David Finkelhor \\ University of New Hampshire - Main Campus, David.Finkelhor@unh.edu \\ Richard Ormrod \\ University of Northern Colorado
}

Follow this and additional works at: https://scholars.unh.edu/ccrc

Part of the Criminology and Criminal Justice Commons, Psychology Commons, and the Sociology Commons

\section{Recommended Citation}

Finkelhor, David \& Ormrod, Richard. Kidnapping of juveniles: Patterns from NIBRS. Juvenile Justice Bulletin - NCJ181161 (pgs. 1-8). Washington, DC: US Government Printing Office.

This Article is brought to you for free and open access by the Research Institutes, Centers and Programs at University of New Hampshire Scholars' Repository. It has been accepted for inclusion in Crimes Against Children Research Center by an authorized administrator of University of New Hampshire Scholars' Repository. For more information, please contact Scholarly.Communication@unh.edu. 


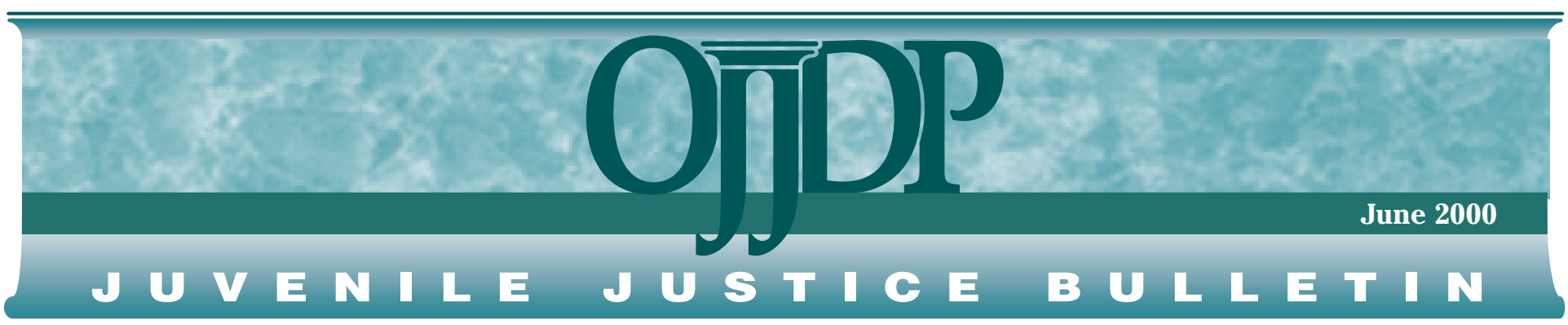

\section{Kidnaping of Juveniles: Patterns From NIBRS}

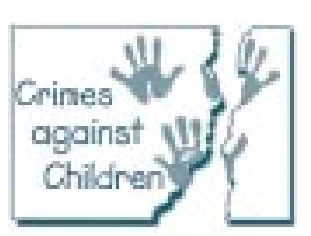

\section{David Finkelhor and Richard Ormrod}

The Office of Juvenile Justice and Delinquency Prevention (OJJDP) is committed to improving the justice system's response to crimes against children. OJJDP recognizes that children are at increased risk for crime victimization. Not only are children the victims of many of the same crimes that victimize adults, they are subject to other crimes, like child abuse and neglect, that are specific to childhood. The impact of these crimes on young victims can be devastating, and the violent or sexual victimization of children can often lead to an intergenerational cycle of violence and abuse. The purpose of OJJDP's Crimes Against Children Series is to improve and expand the Nation's efforts to better serve child victims by presenting the latest information about child victimization, including analyses of crime victimization statistics, studies of child victims and their special needs, and descriptions of programs and approaches that address these needs.

The kidnaping of children has generated a great deal of public concern, not to mention confusion and controversy. These crimes, from the kidnaping of the Lindbergh baby to the abduction and murder of Adam Walsh, have been some of the most notorious and highly publicized news stories of recent history, occupying a central place in the fears and anxieties of parents. Yet, an ongoing debate has raged over how frequently such crimes occur, which children are most at risk, and who the primary offenders are.

Part of the problem has been confusion about the definition of kidnaping. While lengthy ransom abductions and the tragic recovery of bodies have molded the public's perception of the crime, in a strict legal sense, kidnaping also involves both shortterm and short-distance displacements, acts common to many sexual assaults and robberies. Kidnaping occurs whenever a person is taken or detained against his or her will and includes hostage situations, whether or not the victim is moved. Moreover, kidnaping is not limited to the acts of strangers but can be committed by acquaintances, by romantic partners, and, as has been increasingly true in recent years, by parents who are involved in acrimonious custody disputes.

Confusion about kidnaping has been exacerbated by the absence of reliable statistics about the crime. Kidnaping is not one of the crimes included in the Federal Bureau of Investigation's (FBI's) national Uniform Crime Reporting (UCR) system, and individual States or other jurisdictions have rarely made any independent tally of kidnaping statistics. As a result, a national picture of, or even a large data set about,

\section{A Message From OJJDP}

The kidnaping of a child is a crime that tears at the fabric of society. Until recently, the nature and scope of the problem have been unclear because existing crime data collection systemssuch as the FBl's Uniform Crime Reporting (UCR) system and OJJDP's National Incidence Studies of Missing, Abducted, Runaway, and Thrownaway Children-do not collect law enforcement data on kidnaping.

Fortunately, that is about to change. In partnership with the Bureau of Justice Statistics, the FBI is supplanting the UCR with the National Incident-Based Reporting System (NIBRS). This will enhance our understanding of youth abduction and create a comprehensive picture of kidnaping offenses.

This Bulletin describes the offense of kidnaping of juveniles, using 1997 NIBRS data. Among other significant findings, the analysis reveals that such abductions are relatively uncommon, that there are three distinct kinds of perpetrators, and that the rate of juvenile kidnaping peaks in the afternoon.

The better we understand this serious crime, the more effective our efforts will be to prevent and respond to it. NIBRS promises to be an important tool in that process. 
this crime from the law enforcement perspective has been unavailable. In the past, several attempts were made to collect abduction data, but they were limited in scope or time. For example, OJJDP's 1988 National Incidence Studies of Missing, Abducted, Runaway, and Thrownaway Children (NISMART) estimated the number of family and nonfamily abductions for a single year but contained no police data on family abductions (Finkelhor, Hotaling, and Sedlak, 1990, 1991). The Washington State Attorney General's Office has compiled data on abduction homicides known to police, and the FBI has a database on the very serious kidnaping cases that have been reported to it (Hanfland, Keppel, and Weis, 1997; Boudreaux, Lord, and Dutra, 1999). ${ }^{1}$ However, despite these various data sources, a broad picture covering the full spectrum of kidnaping offenses that are reported to and investigated by law enforcement has not been available.

\section{The National Incident- Based Reporting System}

Fortunately, a comprehensive national database on kidnaping and other crimes is beginning to emerge. The FBI, in partnership with the Bureau of Justice Statistics, is supplanting the UCR with the more comprehensive National Incident-Based Reporting System (NIBRS), which collects detailed information on crimes known to the police. One of the improvements introduced by NIBRS is the inclusion of specific data on kidnaping. NIBRS offers an outstanding opportunity to learn more about the nature and extent of this crime, about which so few data have been available in the past.

This Bulletin describes the crime of kidnaping of juveniles (youth ages 17 and younger) as it appears in statistics reported by law enforcement agencies using NIBRS for 1997, the most recent reporting year for which NIBRS data are currently available. An analysis of data on 1,214 juvenile kidnapings from the jurisdictions in 12 States that participated in NIBRS in 1997 reveals the following:

- Kidnaping makes up less than 2 percent of all violent crimes against juveniles reported to police.

$\checkmark$ Based on the identity of the perpetrator, there are three distinct types of kid-

\footnotetext{
${ }^{1}$ Several small-scale studies have also analyzed a series of infant abductions and child molestation abductions (Burgess and Lanning, 1995; Lanning and Burgess, 1995; Prentky et al., 1991)
}

naping: kidnaping by a relative of the victim or "family kidnaping" (49 percent), kidnaping by an acquaintance of the victim or "acquaintance kidnaping" (27 percent), and kidnaping by a stranger to the victim or "stranger kidnaping” (24 percent) (figure 1).

- Family kidnaping is committed primarily by parents, involves a larger percentage of female perpetrators (43 percent) than other types of kidnaping offenses, occurs more frequently to children under 6 , equally victimizes juveniles of both sexes, and most often originates in the home.

- Acquaintance kidnaping has features that suggest it should not be lumped with stranger kidnaping into the single category of nonfamily kidnaping, as has been done in the past.

- Acquaintance kidnaping involves a comparatively high percentage of juvenile perpetrators, has the largest percentage of female and teenage victims, is more often associated with other crimes (especially sexual and physical assault), occurs at homes and residences, and has the highest percentage of injured victims.

- Stranger kidnaping victimizes more females than males, occurs primarily at outdoor locations, victimizes both teenagers and school-age children, is associated with sexual assaults in the case of girl victims and robberies in the case of boy victims (although not exclusively so), and is the type of kidnaping most likely to involve the use of a firearm.

- Relatively little kidnaping involves weapons.

Figure 1: All Violent Crimes Against Juveniles and Juvenile Kidnaping, by Offender's Relationship to the Victim

All Violent Crimes Against Juveniles Juvenile Kidnaping

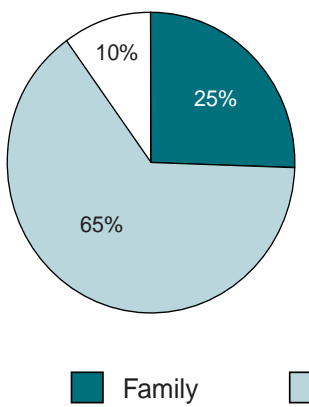

Acquaintance

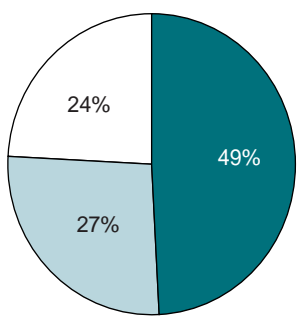

Stranger
- Only one death and a few major injuries were associated with juvenile kidnaping reported to NIBRS.

NIBRS data on kidnaping have some important limitations. Conclusions drawn from these data must be used with caution. he patterns and associations discovered are real, they apply only to the urisdictions reporting and are not necesand dynamics of crime. Also, NIBRS relies on local law enforcement agencies to coldata, and it is not clear how systematic agencies are in their recording of kidnaping. Because kidnaping is not included in UCR data, agencies may not yet code for kidnaping as thoroughly as they might for other crimes. Moreover, jurisdictions may vary in how regularly they charge offenders with the crime of kidnaping. The elements of kidnaping exist in a wide range of criminal incidents-sexual assaults, robberies, and physical assaults-yet some jurisdictions, for a variety of possible reasons such as training, tradition, or local statutes, may charge or record the crime of kidnaping more or less frequently than other crimes.

Nonetheless, current NIBRS data provide a picture of the types of incidents law enforcement agencies in participating jurisdictions across the country are recording statistical purposes as the crime of kidnaping. This perspective of current law enforcement practices is important in and because, unlike public perceptions and prevailing stereotypes, it represents the actual juvenile kidnaping that police in these jurisdictions deal with on a day-to-day basis.

Source: Federal Bureau of Investigation, 1997. 


\section{The National Incident- Based Reporting System}

The U.S. Department of Justice is supplanting its Uniform Crime Report (UCR) system with a more comprehensive National Incident-Based Reporting System (NIBRS). Although NIBRS holds great promise, it is still far from a national system. Its implementation by the FBI began in 1988 , and participation by States and local agencies is voluntary and incremental. By 1995, jurisdictions in 9 States had agencies contributing data; by 1997, the number was 12 ; and by the end of 1999, jurisdictions in 17 States submitted reports, providing coverage for 11 percent of the Nation's population and 9 percent of its crime. Only 3 States (Idaho, lowa, South Carolina) have participation from all local jurisdictions, and only 1 city with a population currently greater than 500,000 (Austin, TX) is reporting, leaving the crime experiences of large urban areas particularly underrepresented.

Nevertheless, the system is assembling large amounts of crime information and providing a richness of detail about juvenile victimizations that was previously unavailable. The patterns and associations these data reveal are real and represent the experiences of a large number of youth. The 1997 NIBRS data file contains information on 364,830 violent crimes against individuals, with 79,028 of these against juveniles.

A more detailed discussion of the NIBRS data can be found in the authors' recently published OJJDP Bulletin, Characteristics of Crimes Against Juveniles (NCJ 179034).

\section{Juvenile Kidnaping- A Rare Occurrence}

Data indicate that kidnaping of juveniles is a relatively rare crime in NIBRS jurisdictions. It constitutes only one-tenth of 1 percent of all the crimes against individuals, 1 percent of all crimes against juveniles, and 1.5 percent of all violent crimes against juveniles recorded in the database. Kidnaping is dwarfed by the much more common crimes of simple and aggravated assault, larceny, and sex offenses, which make up most of the crimes against juveniles (Finkelhor and Ormrod, 2000). Both the limited coverage of NIBRS and the fact that kidnapings represent a very small percentage of all crimes make it impossible to project a reliable national estimate of kidnaping incidents. Nonetheless, the 1,214 juvenile kidnaping cases in the 1997 NIBRS data provide a larger database than has been previously available for examining the characteristics of this crime.

Kidnaping is widely recognized to involve very different dynamics and motives depending on the identity of the perpetrators and age of the victim (Boudreaux, Lord, and Dutra, 1999; Finkelhor, Hotaling, and Sedlack, 1990; Forst and Blomquist, 1991). Previous research and current public policy divide kidnaping into two categories: family abductions and nonfamily abductions. Family abductions are usually committed by parents who, in the course of custodial disputes, take or keep children in violation of custody orders (Plass, 1998). Nonfamily abductions are generally thought to involve efforts, primarily by strangers, to isolate children in order to commit another crime, such as sexual assault or robbery.

\section{Three Types of Perpetrators}

In contrast, the criminal kidnaping of juveniles, as recorded by police in the NIBRS jurisdictions, is divided into three relatively large categories: family kidnaping (49 percent), acquaintance kidnaping (27 percent), and stranger kidnaping (24 percent) (figure 1). Compared with all violent crimes against juveniles, kidnaping has substantially higher percentages of both family and stranger perpetrators, but the high percentage of acquaintance kidnapings is striking given previous characterizations of this crime that have emphasized only the family and stranger elements.

In the NIBRS jurisdictions, family kidnaping perpetrators are usually parents (80 percent), almost always adults (98 percent), and often female (43 percent) (figures 2 and 3 ). Although not a majority of family kidnaping perpetrators, females commit a substantially larger portion of the family abductions than they do of acquaintance abductions (16 percent), stranger abductions ( 5 percent), or violent crimes in general (24 percent).

Stranger perpetrators are predominately males (95 percent) and predominately adults (90 percent) (figures 2 and 3). Acquaintance kidnaping has the largest proportion of juvenile offenders (30 percent) and a some- what higher percentage of female offenders than stranger kidnaping (16 percent and 5 percent, respectively). Data from the NIBRS jurisdictions provide limited information about the characteristics of some offenders in the acquaintance category. Eighteen percent are categorized as boyfriend, which suggests a quite distinct dynamic, whereas two other subdivisionsfriend ( 7 percent) and acquaintance (73 percent)—although more ambiguous, suggest different degrees of intimacy or familiarity.

Family perpetrators kidnap males and females in approximately equal proportions (figure 3). Acquaintance perpetrators kidnap substantially more females than males (72 percent and 28 percent, respectively). Stranger perpetrators also kidnap more females than males but not quite so disproportionately as acquaintances (64 percent and 36 percent, respectively).

\section{Figure 2: Juvenile Kidnaping, by Offender's Relation- ship to the Victim and Offender's Gender}

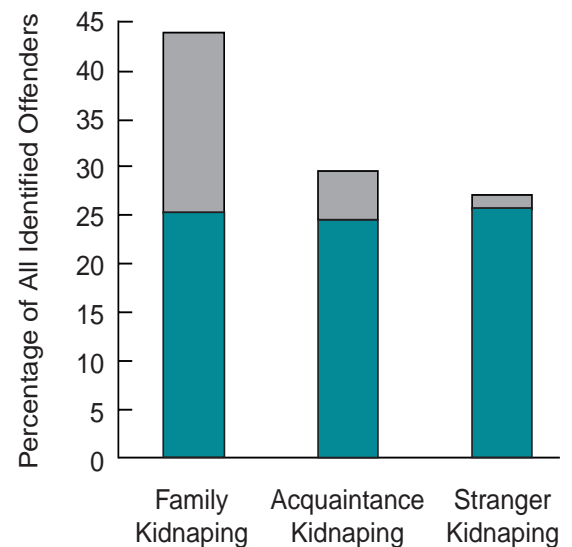

Male Offender Female Offender

Note: What may appear to be inconsistencies in the proportions of the three types of juvenile kidnaping presented in figures 1 and 2 are the result of the different methods of analyzing NIBRS data used in each figure. Figure 1 analyzes incidents of juvenile kidnaping. Figure 2 analyzes juvenile kidnaping offenders. Thus, for example, in part because one kidnaping incident may involve more than one offender, figure 1 shows that 49 percent of all juvenile kidnapings are committed by family members, while figure 2 shows that 44 percent of all kidnaping offenders are family members.

Source: Federal Bureau of Investigation, 1997 


\section{Figure 3: Juvenile Kidnaping, by Offender's Relationship to the Victim, Victim's Gender, and Offender's Age Group}

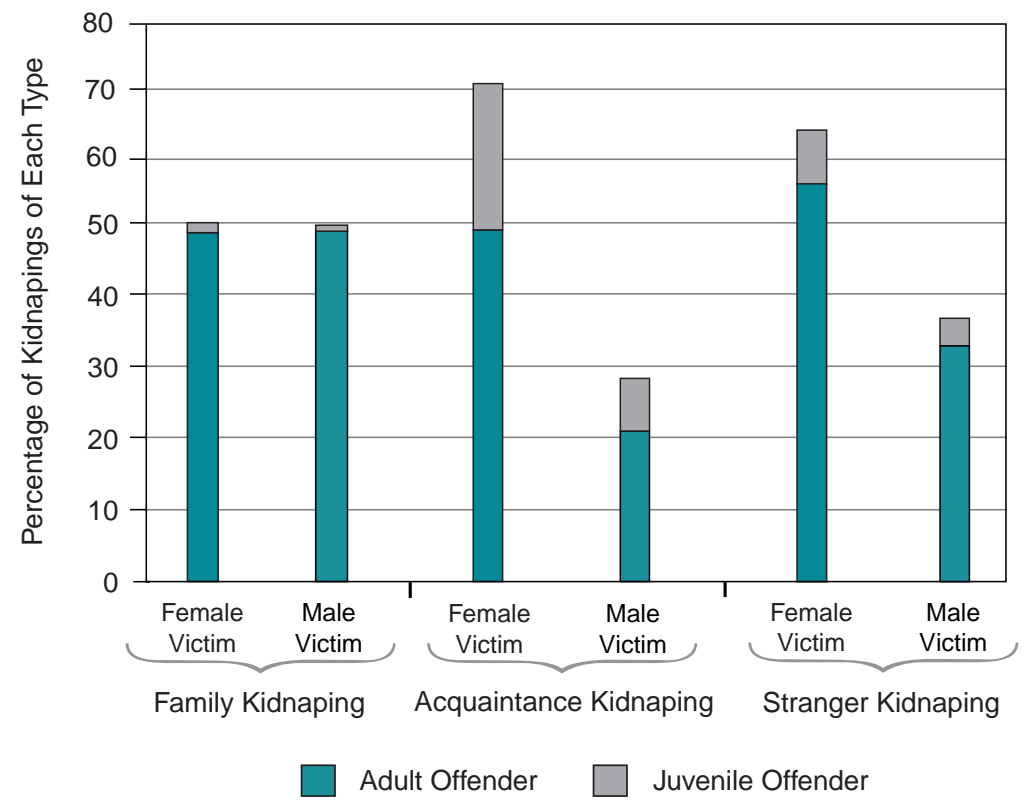

Source: Federal Bureau of Investigation, 1997.
In the NIBRS jurisdictions, family kidnaping, consistent with the stereotype, is associated primarily with homes and residences (84 percent) (figure 5). Stranger kidnaping, by contrast, is associated primarily with outdoor locations (58 percent)—streets, highways, parks, waterways, and other public areas. Like family kidnaping, most acquaintance kidnaping takes place at homes and residences (63 percent), but unlike family kidnaping, a substantial percentage of acquaintance kidnaping also occurs in outside locations (22 percent). It is important to note that schools are an unusual site for abduction, even family abduction (only 5 percent of family, 4 percent of acquaintance, and 3 percent of stranger kidnaping occur at school).

\section{Additional Offenses}

In other studies, nonfamily kidnaping is generally associated with other offenses, such as robbery or sexual assault, and is in fact a means of facilitating those offenses. One advantage of NIBRS over UCR is its ability to code multiple crimes associated with a single incident. Overall, 19 percent of the juvenile kidnaping reported in NIBRS jurisdictions is associated with another violent crime. This makes it the most common crime to be paired with an additional offense. These additional offenses provide some perspective on the motives of kidnaping offenders.

Most additional offenses associated with kidnaping occur in conjunction with

\section{Victim Age Patterns}

The three categories of kidnaping also have distinct patterns with respect to the age of victims. In the NIBRS incident reports, family kidnaping has its peak occurrence for children under age 6 (43 percent), while a large majority of acquaintance kidnaping victimizes teenagers (youth ages 12 to 17 ) (71 percent). Stranger kidnaping is more equally split between teenage and elementary school-age victims (57 percent and 32 percent, respectively). However, the risks for children of different ages appear to have a complex interplay (figure 4). Children under the age of 6 are primarily targets of family kidnaping, which peaks at about age 2 and declines thereafter. The risk of kidnaping by a stranger is comparatively low for preschoolers but rises throughout the elementary school years and reaches its peak around age 15. Acquaintance kidnaping is the predominant problem for teenagers, displacing stranger kidnaping as their biggest threat.

\section{Location}

NIBRS provides only crude data about the location of crimes, particularly a crime like kidnaping that may have an originating, intermediate, and destination locale (for example, a child taken from a street, driven in a car, brought into a residence, and then raped). NIBRS allows multiple-location coding for multiple-offense crimes, but only 1 percent of incidents involving kidnaping have multiple locations recorded in NIBRS data. The information on location does, however, show clear-cut associations between the offender's relationship to the victim and the location of the kidnaping.

\section{Figure 4: Juvenile Kidnaping, by Victim's Age and Offender's Relationship to the Victim}

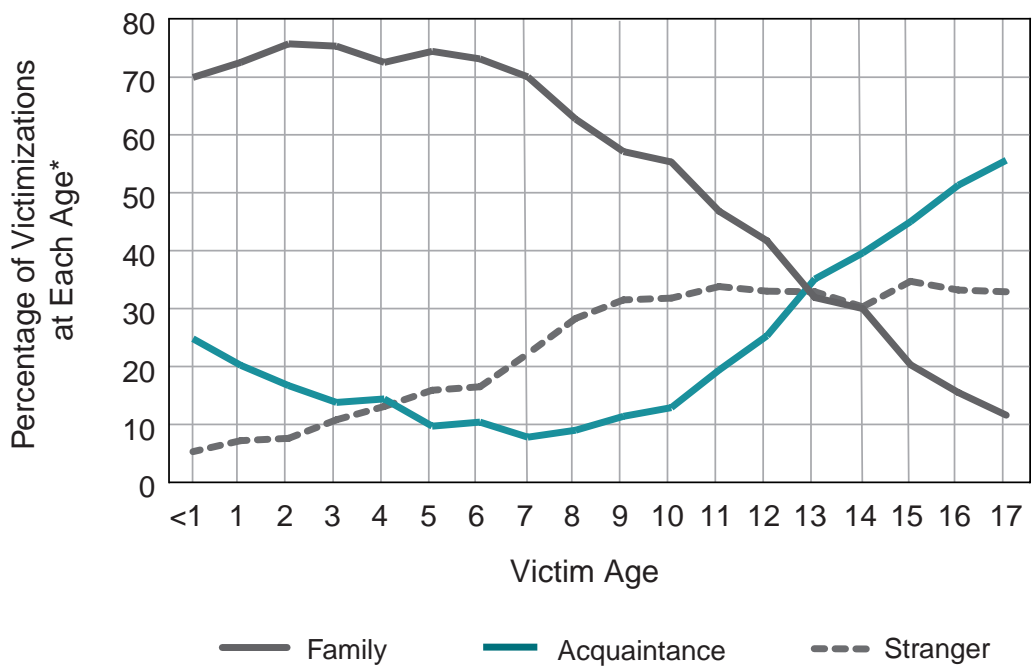

${ }^{*}$ Three-year running average.

Source: Federal Bureau of Investigation, 1997 
acquaintance and stranger kidnaping, but the types of offenses vary somewhat according to the gender of the victim (figure 6). For female victims, sex crimes were the predominant adjunct to kidnaping, occurring in 23 percent of the kidnapings by acquaintances and 14 percent of the kidnapings by strangers reported to NIBRS in 1997. For male victims, robbery and assault were the additional offenses most likely to accompany kidnaping, although some sex offenses also occurred.

Family kidnaping tends not to be associated with any other crime. In this type of kidnaping, none of the offenses against boys and only 5 percent of the offenses against girls were linked to an additional violent crime.

\section{Weapon Usage}

For the most part in NIBRS jurisdictions, kidnaping is a weaponless crime (figure 7). Approximately 14 percent of acquaintance kidnapings and about 23 percent of stranger abductions involved weapons, mostly guns. The use of weapons in family abductions was quite rare (less than 2 percent).

\section{Injuries and Deaths}

Injuries occurred in only 12 percent of all kidnapings recorded by police in participating jurisdictions. They were most frequent in acquaintance abductions (24 percent) and least frequent in family abductions (4 percent) (figure 8). Major injuries (for example, severe lacerations, broken bones, unconsciousness) were extremely rare, occurring in only 2 percent of all kidnapings. Only one fatal outcome to a kidnaping was recorded in the 1997 NIBRS data. When interpreting figure 8 , however, it must be kept in mind that these abductions were not necessarily crime episodes of long duration or ones in which a child was officially declared missing. They could have involved episodes during which a child was transported a short distance or into a building or car in order to accomplish a sexual assault or robbery. NIBRS has no usable information about whether the child victim was at any time in the episode reported missing or about the distance or duration of the kidnaping.

\section{Time of Day}

Rates for all crimes against children peak in the afternoon (Snyder and Sickmund, 1999), and kidnaping is no exception: 41 percent of all juvenile kidnapings in NIBRS jurisdictions occur during afternoon hours (noon to 6 p.m.). The main difference among the three types of kid-

\section{Figure 5: Juvenile Kidnaping, by Offender's Relationship to the Victim and Type of Location}

Family Kidnaping

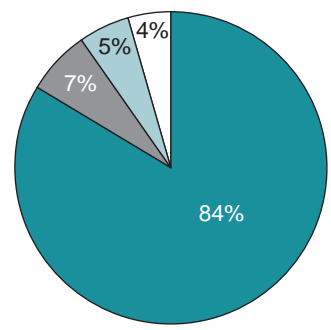

Residence/Home
Acquaintance Kidnaping

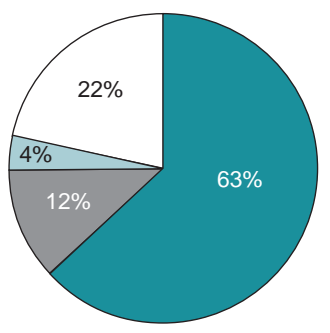

Other Building

\section{Stranger Kidnaping}

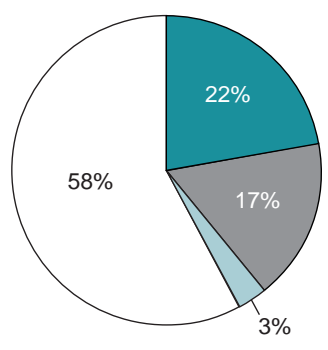

School

Outside
Note: Percentages may not total 100 percent because of rounding.

Source: Federal Bureau of Investigation, 1997.

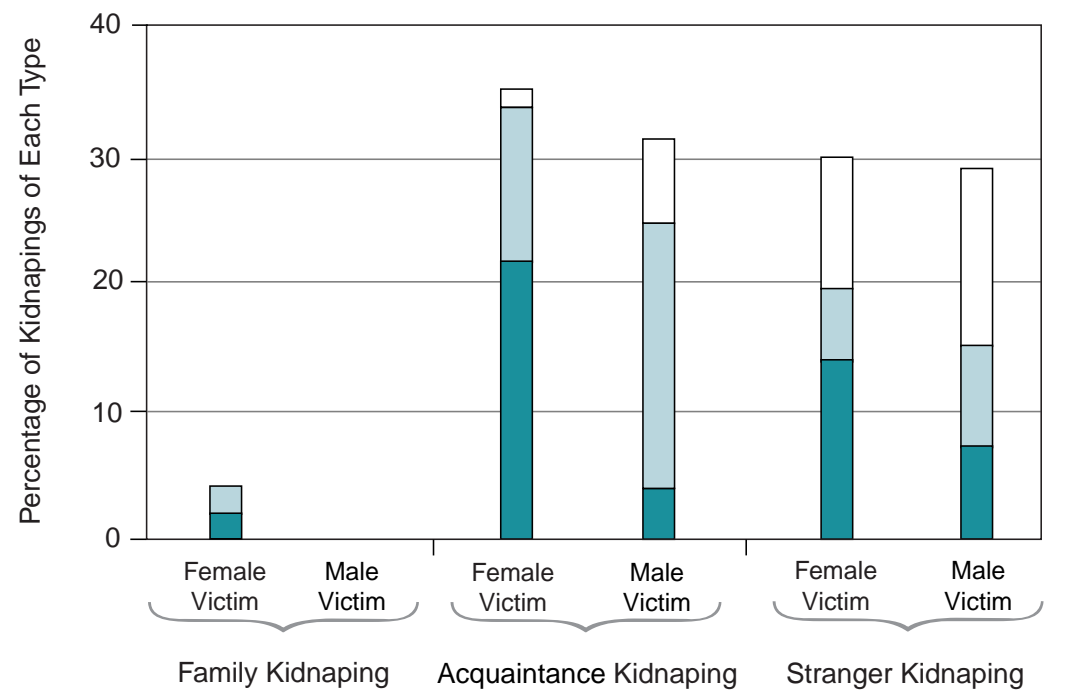

Additional Offenses: $\square$ Sex Offense $\quad \square$ Assault $\quad \square$ Robbery

Source: Federal Bureau of Investigation, 1997.

naping is that acquaintance and stranger kidnaping are somewhat more likely than family kidnaping to occur in the evening (6 p.m. to midnight) or nighttime (midnight to 6 a.m.) hours (46 percent, 41 percent, and 30 percent, respectively) (figure 9).

\section{Implications}

NIBRS data from the jurisdictions reporting in 1997 suggest that the current practice of differentiating the crime of kidnaping into only two categories (family and nonfamily) needs to be changed. The two components of the conventional nonfamily 
category-acquaintance kidnaping and stranger kidnaping-seem to be different types of offenses, at least as they appear in law enforcement data. The specific characteristics of acquaintance kidnaping, which has not yet been separately profiled, need to be better delineated and understood.

Acquaintance kidnaping in data from NIBRS jurisdictions distinguishes itself from stranger kidnaping in a variety of important ways (table 1). First, it involves more juvenile offenders and somewhat more female offenders. Second, it occurs more often with teenage victims, while more stranger kidnaping victimizes school-age children (the complement of "teenage victim"). Third, acquaintance kidnaping is much more likely to occur at a home or residence, while stranger kidnaping most often occurs in outdoor locales. Finally, acquaintance kidnaping victims suffer a higher rate of injury. These substantial differences highlight that acquaintance kidnaping is both a separate and serious form of kidnaping.

Unfortunately, because of the limited categories of information available in NIBRS, it is impossible to draw confident conclusions about the dynamics and motives that might specially characterize acquaintance kidnaping. Nevertheless, NIBRS data are consistent with case material suggesting that certain specific types of crimes are encompassed within the acquaintance kidnaping category. For example, one specific type of acquaintance kidnaping is the situation where boyfriends or former boyfriends kidnap girlfriends (32 percent of the acquaintance kidnaping of teenage female victims) to seek revenge for being spurned, force a reconciliation, commit a sexual assault, or perhaps evade parents who want to break up the relationship. Another type of acquaintance kidnaping is related to gang activity: for example, the situation where teenagers abduct other teenagers in order to intimidate, recruit, or retaliate against them. A third type of acquaintance kidnaping involves family friends or employees (for example, babysitters) who remove children from their home for the purpose of sexual assault or perhaps retaliation against the family. Such variety of offenders and motives may make acquaintance kidnaping more difficult to typify than family or stranger kidnaping, but it is nevertheless instructive in that it highlights the importance of obtaining data on a larger number of cases for the purposes of profiling.

There is no easy explanation for why acquaintance kidnaping involves more injury than stranger kidnaping. It may be the combination of more teenage victims who

\section{Figure 7: Juvenile Kidnaping, by Offender's Relationship to the Victim and Presence of Firearm, Knife, or Blunt Object}

Family Kidnaping

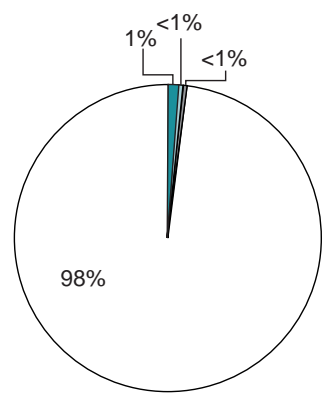

Firearm
Acquaintance Kidnaping

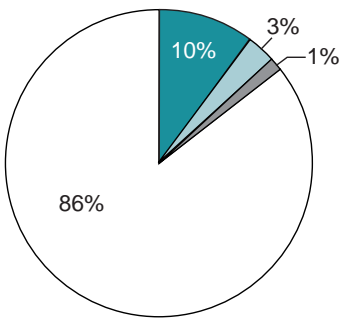

Knife
Stranger Kidnaping

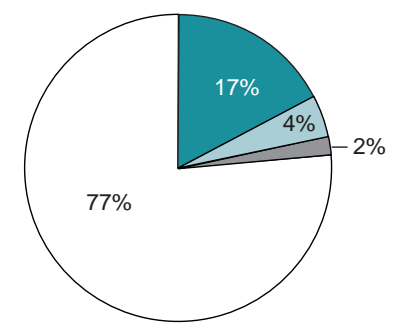

None Present
Note: Percentages may not total 100 percent because of rounding.

Source: Federal Bureau of Investigation, 1997. would be inclined to resist and the fact that intimidation is a more common motive for these crimes, which results in the use of more force and thus more injury. It may also be that police are less likely to think of kidnaping as an element in an acquaintance crime (and thus less likely to record kidnaping as an additional offense in the NIBRS database) unless the victim is injured.

It is also instructive to examine the discrepancies between the pictures of nonfamily kidnaping presented in NIBRS data and those found in the data collected by the earlier NISMART, which conducted an independent review of police files (abduction, miss- ing persons, homicide, and sexual assault files) in 1988 (Finkelhor, Hotaling, and Sedlak, 1990). NISMART data record fewer acquaintance and juvenile perpetrators but substantially more weapon usage. Another significant discrepancy is in the percentage of kidnaping incidents associated explicitly with sexual assault. In NISMART, sexual assault appeared to be a motive in two-thirds of the nonfamily abductions known to police (Asdigian, Finkelhor, and Hotaling, 1995), whereas in NIBRS, only 15 percent of nonfamily kidnaping (of both male and female victims) was coded with the additional crime of sexual assault.

\section{Figure 8: Juvenile Kidnaping, by Offender's Relationship to the Victim and Victim's Injury}

Family Kidnaping

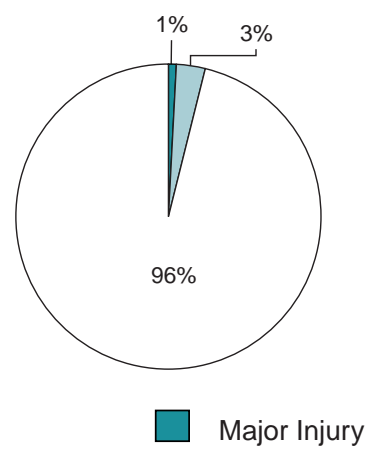

Note: Percentages may not total 100 percent because of rounding.

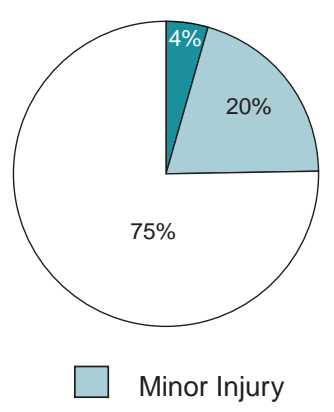

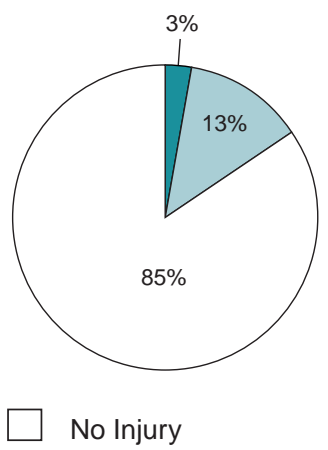

Source: Federal Bureau of Investigation, 1997. 


\section{Figure 9: Juvenile Kidnaping, by Offender's Relationship to the Victim and Time of Day}

Family Kidnaping

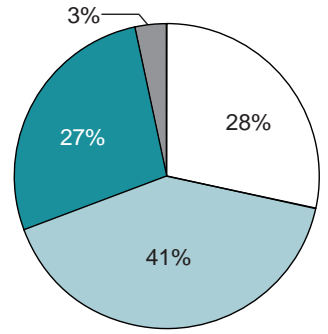

Morning (6-12)
Acquaintance Kidnaping

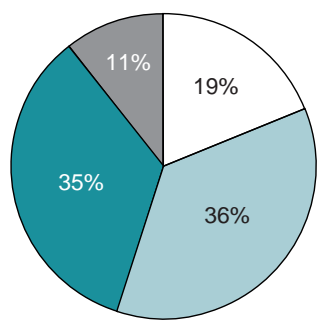

Afternoon (12-6)

\section{Stranger Kidnaping}

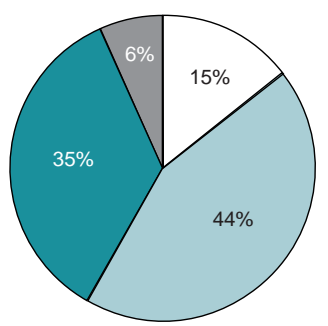

Night (12-6)

Note: Percentages may not total 100 percent because of rounding.

Source: Federal Bureau of Investigation, 1997.

There are several possible explanations for these differences. The methodology used in NISMART to look for abductions was to directly sample police departments' sexual assault files but not their general assault or robbery files, which may have exaggerated the portion of kidnaping that was associated with sexual assault. At the same time, NISMART's direct access to police files may have revealed sexual assault motives or intentions that are not captured when officers apply NIBRS codes. It is certainly surprising that so much of the stranger and acquaintance kidnaping recorded in NIBRS has no other crime associated with it, because these types of kidnaping are generally considered as primarily a method to facilitate other offenses. One problem might be that law enforcement officials, continuing the UCR tradition with its single-code limit, do not take advantage of the multiple crime codes allowed under NIBRS and fail to record adjunct or secondary offenses. For whatever reason, NIBRS may underrep- resent the motive of sexual assault and the presence of other crimes in acquaintance and stranger kidnaping.

Another conspicuous discrepancy between NIBRS and NISMART data concerns the relative occurrence of family and nonfamily abduction. The NISMART data suggest that the overwhelming majority of abductions were committed by family members (Finkelhor et al., 1990), whereas family abductions actually constitute only a slight minority of all kidnapings recorded in NIBRS. However, the NISMART family abduction estimates come from a national household survey, not police records, and, although 44 percent of the families surveyed indicated they had contacted police, relatively little is known about how such reports are recorded or tabulated in crime statistics. The discrepancy between the NISMART and NIBRS data suggests that many, if not most, calls to police about family abductions are not recorded as crimes.

\section{Table 1: Key Differences Between Acquaintance and Stranger Abductions}

Percentage of Victimizations With Characteristic

\section{Characteristic}

Any juvenile offender

Any female offender

Teenage victim

Home or residence location

Outside location

Injury to victim

Acquaintance $(n=244) \quad$ Stranger $(n=221)$

27

17

71

63

22

25
Findings on kidnaping from the NIBRS jurisdictions also are inconsistent with other kidnaping studies-for example, those based on FBI data or national inquiries of police investigators (Boudreaux, Lord, and Dutra, 1999; Hanfland, Keppel, and Weis, 1997) - concerning characteristics such as the identity of perpetrators or the incidence of serious injury and death. These differences can almost all be traced to the different samples selected in different studies-for example, samples of kidnaping homicides. What is really highlighted by all of these comparisons is the absence of a consensus about how segments of the population of kidnaped children should be aggregated or subdivided for most useful policy analysis. NIBRS data provide yet another, but by no means a complete or conclusive, perspective on the problem.

The inconclusiveness of findings about kidnaping point to the main policy needs in this area. First, substantially more research about this crime-which has attracted a large amount of public attention but rather little scientific study or profilingis needed. Second, research about the problem would benefit if those studying and collecting data about it would adopt a common set of definitions and categories within which to subdivide and analyze it. This uniformity has been achieved in regard to other crimes (e.g., sexual assault) in recent years as a result of national data systems like the UCR, but kidnaping was outside the purview of this system. The inclusion of kidnaping in NIBRS offers the opportunity to achieve that uniformity now. Third, in the light of this and in order to increase the usefulness of NIBRS for the study of kidnaping, NIBRS may need to make a special effort to help local agencies report kidnaping in uniform and consistent ways, since it is a crime that may be handled in disparate fashions from jurisdiction to jurisdiction.

\section{Conclusion}

NIBRS, as it grows, will increasingly facilitate new insights into the dynamics of crime. This may be nowhere more apparent than in dealing with the crime of kidnaping, for which there have been few data sources. Although the quality of NIBRS data on kidnaping is unclear, this new national database will allow a more systematic analysis of kidnaping across jurisdictions and over time. The availability of such data may even prompt efforts to better define and categorize the crime of kidnaping and to improve the reliability of its coding. These 
Office of Justice Programs

Washington, DC 20531

Official Business

Penalty for Private Use $\$ 300$

are small but crucial steps on the path to improving law enforcement's understanding of and response to this crime.

\section{References}

Asdigian, N.L., Finkelhor, D., and Hotaling, G.T. 1995. Varieties of non-family abduction of children and adolescents. Criminal Justice and Behavior 22(3):215-232.

Boudreaux, M.C., Lord, W.D., and Dutra, R.L. 1999. Child abductions: Age-based analyses of offender, victim, and offense characteristics in 550 cases of alleged child disappearance. Journal of Forensic Sciences 44(3):531-545.

Burgess, A.W., and Lanning, K.V. 1995. An Analysis of Infant Abductions. Alexandria, VA: National Center for Missing and Exploited Children.

Federal Bureau of Investigation. 1997. National Incident-Based Reporting System (NIBRS). (12 States only). Computer file. Tabulations undertaken by Crimes Against Children Research Center. Washington, DC: U.S. Department of Justice, Federal Bureau of Investigation.

Finkelhor, D., Hotaling, G.T., and Sedlak, A. 1990. Missing, Abducted, Runaway, and Thrownaway Children in America: First Report. Washington, DC: U.S. Department of Justice, Office of Justice Programs, Office of Juvenile Justice and Delinquency Prevention.
Finkelhor, D., Hotaling, G.T., and Sedlak, A. 1991. Children abducted by family members: A national household survey of incidence and episode characteristics. Journal of Marriage and the Family 53(2):805-817.

Finkelhor, D., and Ormrod, R. 2000. The Characteristics of Crimes Against Juveniles. Bulletin. Washington, DC: U.S. Department of Justice, Office of Justice Programs, Office of Juvenile Justice and Delinquency Prevention.

Forst, M.L., and Blomquist, M. 1991. Missing Children: Rhetoric and Reality. New York, NY: Lexington Books.

Hanfland, K.A., Keppel, R.D., and Weis, J.G. 1997. Case Management for Missing Children Homicide Investigation. Washington State: Attorney General of Washington.

Lanning, K.V., and Burgess, A.W. 1995. Child Molesters Who Abduct: Summary of the Case in Point Series. Alexandria, VA: National Center for Missing and Exploited Children.

Plass, P.S. 1998. A typology of family abduction events. Child Maltreatment 3(3):244-250.

Prentky, R.A., Knight, R.A., Burgess, A.W., Ressler, R., Campbell, J., and Lanning, K.U. 1991. Child molesters who abduct. Violence and Victims 6(3):213-224.

Snyder, H.N., and Sickmund, M. 1999. Juvenile Offenders and Victims: 1999 National Report.
This Bulletin was prepared under grant number 98-JN-FX-0012 from the Office of Juvenile Justice and Delinquency Prevention, U.S. Department of Justice.

Points of view or opinions expressed in this document are those of the authors and do not necessarily represent the official position or policies of OJJDP or the U.S. Department of Justice.

The Office of Juvenile Justice and Delinquency Prevention is a component of the Office of Justice Programs, which also includes the Bureau of Justice Assistance, the Bureau of Justice Statistics, the National Institute of Justice, and the Office for Victims of Crime.

\section{Acknowledgments}

This Bulletin was prepared by David Finkelhor, Ph.D., Professor of Sociology, and Director, Crimes Against Children Research Center, University of New Hampshire; and Richard Ormrod, Ph.D., Research Scientist, Crimes Against Children Research Center, University of New Hampshire. 